\title{
The Historical Review on the Process of National Identity Formation
}

\author{
Mahdi Shahin \\ Department of Political Sciences, Faculty of Letters and Humanities, Lorestan University, Khoramabad, Iran \\ Email: mahdishahin4389@yahoo.com
}

\section{Doi:10.5901/mjss.2016.v7n1s1p111}

\begin{abstract}
Given the importance of national identity in a country's actions and discussion on the national unity as a prerequisite for other social measures, recognition of national identity elements in historical periods and their carriers is very important. Therefore, this article historically reviews the development of the national identity and finds out what factors are involved in the formation of Iranian identity. It alsoanalyzes historical periodsto explain the background of Iran's national identity formation. Furthermore, it was based on library studies and traditional and electronic library resources, books and articles published in journals were used. In this study, descriptive and analytical method was used to analyze the data according to the type of research. The purpose of this research is that the social - cultural phenomena are product of specific historical conditions of countries, the researcher believes that with regard to the specific circumstances of Iran, the nation and consequently the national identity have been in the past history of this country.
\end{abstract}

Keywords: History; identity; nationality; Iran;State

\section{Introduction and Problem Statement}

The question related to identity, especially in the past few decades, isundoubtedly one of the most important questions in the field of relations between individuals and communities. This question has always been at the focus of mass attention and also has provided an area for interpretation and evaluation of any expression or statement. Widespread attention to the question, regardless of their different origins, shows the importance of identity.On the other hand, the diversity and contradictions which are directly and indirectly provided on the concept of identity represent its complexity. As a result, it creates ideal conditions for further investigation on the identity.Different interpretations can be given on the concept of identity that each one proposes different requirements, priorities, concerns and hopes. These differences are resulted from a variety of views about the issue. Edward Said in his book entitled "Eastern studies" provides clues to understand the sources of these differences.In the preface of this book, two kinds of "civil society" and "political society" are introduced. According to his especial definition on civil society, this society accepts institutional participation as the main component and continues its lives by changes resulted from the new experience of the institutions.Political society is made up of central administrative organizations which their main task issystematizingand stabilizing the situation.According to the differences between two societies, different interpretations arise from the basic conceptswhich naturally cover value systems and also artistic and cultural works(MoieniAlamdari, 2004, p.37).

The identity of a nation is the thousand year legacy of the efforts of past generations of the nation.Every generation transfersits cultural and national resourcesand experiences of its life to the next generation in many ways. The next generation also adds its resources to it and transfers it to the next generations after itself.This process has continued throughout history.As a person's character isresulted from his personal experiences and causes his superiority over other people, the identity of a society and the nation is also resulted fromthe thousand yearbittersweet experiences of the nation. There has always been a difference between thinkers and scholars on the components and elements of the society identity which have been shaped over the past generations and distinguish it from other societies. Can a nation have a real identity? Can we make an artificial and unreal identity for a nation? How is the process of identity formation for a nation?As an example, what identity and components of the identity are appropriate for Iranian nation?What doconsistency and durability of the identities depend on? What does the essence identity emphasize on?

In this context, scholars and historians consider historical identities for Iranians throughout history full of ups and downs: (1) Iranian identity in the Sasanian period; (2) Islamic-Iranian identity or Iranian cultural-historical identity from the $4^{\text {th }}$ to $5^{\text {th }}$ century; (3) tribal identity and religious identity from the $6^{\text {th }}$ to the $13^{\text {th }}$ century; (4) The Iranian new identity, a new Iranianness in the Qajar and Pahlavi periods (Salasi, 2008, p.54).To understand the most important events and developments in the history of Iran's, some important historical transformations from the arrival of Islam to the ninth 
century include:1. arrival of Islam in Iran; 2. Mongol invasion; 3. Ismaili movement; 4. the advent of the Safavid. The most important event was the advent of the Safavids after the 9th century, a powerful government in Iran which createdthe political independence, geographical and religious unity and power centrality.Iran achieved the growth, prosperity and development in the light of national, economic and social security in the Safavid era (Najafi and FaghihHaghani, 2002, p.71).Thus, the Iraniansrecovered their true identity in the light of the first independent and comprehensive government at thegeographical borders of Iran. In this context, the civilized and ancient of Iran's nation rooted throughout the history of the worldhas the ancient civilization. As a result, a nation with this ancient history can't be indifferent to their history. Many evidences suggest that Iranian people have never been indifferent to their history; so that we can certainly say:One of the most important factors of maintaining identity, independence, and openness of the Iranian nation, in spite of the devastating events of the past in this country, is the historical mentality of the people in this land. At the same time, recognition of the historical identity of the Iranian people, who have an ancient history, requires a lot of researches and exploration to make the historical identity of this land more transparent(Dashti, 1995, p. 27). Hence, the research question is that: are the Iranian nation and national identity made up of the historical roots or contemporary Iran? In response to this question and given the fact that the social - cultural phenomena are product of specific historical conditions of countries, the researcher believes that with regard to the specific circumstances of Iran, the nation and consequently the national identity have been in the past history of this country. The definition of concepts such as identity, nation, national identity and Iranian national identity will be taken into account as follows. Then, historical periods will be analyzed to describe the areas of identity formation and the Iranian nation.

\section{Methodology}

The study is a theoretical research and the method is descriptive and analytical.Furthermore, it was based on library studies and traditional and electronic library resources, books and articles published in journals were used. In general, methods in this article are based on writings about the historical study of the formation of national identity and to some extent usingthe descriptive and analytical approach.

\section{Definition of Concepts}

1) Identity: The word «ldentity» is derived from «ldentitas» and defined by two opposing concepts:Similarities and differences. Therefore, when it is said: the nation or the individual has the specific identity, it means that this one, like others, has the same identity (Similarity) and at the same time, such a nation and individual has a distinct identity and unique features (difference). In other words, having identity means being unique but it is different from two aspects: being like others in the society and class and being like oneself over time. From one perspective, the identity is the attitude toward oneself. Oneself refers to the one's characteristics (Rajaee, 2002) and typically involves individual perceptions and feelings about the body, personal competences, and having a clear picture of oneself and dignity. From the other perspective, it is the attitude toward outside in which the relationship between oneself and others is determined (Erikson, 1959).

In fact, the identity is a collection of the attitudes, characteristics and spirit that distinguishes oneself from the others. Thus, the identity can be investigated from two dimensions and aspects.

- The individual dimension is to foster individuals' character of a nation and preparing them for their future life.

- The social dimension and the impact of a nation's identity to lead society to the national unity and the social cohesion.

Of course, these dimensions are not separated from each other. This means that from the personal and psychological perspective, each person going through puberty should achieve such a degree of selfknowledge and character stability to play a positive role in society and also achieve social identity (Leonard, 2010).

On the other hand, a nation also has an independent identity. This identity makes his characterindependent that is quite distinct from the others. The people of this nation have always been proud of their national identity and commit to the distinctive elements of their nation. Belonging to a common race, language, geography, religion, history and culture and ... are the identity elements of a nation. In case of danger and crisis, this identity leads to unity, Alliance, solidarity, and harmony of the nation. Individuals and society having a single national identity are considered as a single nation whose people having a sense of belonging to each other. Belonging to a land with a single language is other aspect of national identity. Identification for a person or 
nation is so vital that if they fail to meet this need in a way, mental, personal and national health will be seriously injured. For identity of the person and of society, self-concept should be made in a way that involvesthe continuity and connection to the past and orientation towards the future (Fakohi, 2002).

2) Nation: Ernest Renanwas an important French theorist who defines nation as follows: "A nation is a soul, a spiritual principle. Two things, which in truth are but one, constitute this soul or spiritual principle. (1)a rich legacy; (2)consent, the desire to live together,the will to perpetuate the value of the heritage that one has received in an undivided form. This definition has tried to express both historical and cultural heritage of the people as the fundamental cause of "being a nation". For this reason, it has also considered its democratic nature (Dehshir, 2001, p. 9).

3) National identity: national identity means going through traditional identities such as religion, ethnic, tribal and reaching pervasive identities. According to the national identity, individuals identify themselvesbased on belonging to a particular nation with the specific geography and a certain governmental system rather than their tribal and ethnic affiliations.National identity should be so pervasive that does not create a conflict between the primary identity (individual- ethnic) and the universal identity (national).According to thisdefinition, features of the national identity can besummarized as follows: 1. a particular nation; 2. Geography of the homeland;3. a certain governmental system.

4) Iranian national identity:That aspect of the intellectual framework or a form of self-consciousness of the nation asa leaven in the history of social transformation of Iran and Iranians are ongoing and gives their collective life continuity and stability. This paradox represents a stable and dynamic nation. It means that societies are continuously transforming and there are aspects of stability in their culture in a way that this transformation rotates around them and do not allow the society to be changed. Iran's national culture features include Iran, tradition, religion, and modernity (Sheikhavandi, 2001).

Professor Morteza Motahari (1986) believed that although the standard of language and culture and historical and ethnic backgrounds are effective in the development of a nation,they are not always essential.He considered the identity as the common sense or conscience among some people that makes a political unit or nation. According to him, the Iranian identity has two basics: (1) being Iranian; (2) being Islamic. Ahmadi (2003) considers the foundations of national identity as follows: 1. history of Iran, 2. Land and geography, 3. Legacy and institution of government, 4. The Iranian cultural heritage, 5. religious and spiritual heritage of Iran, 6. community and the Iranian people. He emphasizes on the community and the people of Iranto provide a distinct definition and the more modern approach for the concept of identity.

\section{Factors Andcontexts of the National Identity Development}

The factors underlying the development of national identity can be outlined as follows:

1. Sense of belonging to culture, civilization and nationality: one of the causes of identity emergence, sense of belonging to a culture, civilization and specific nationality. It means that the society should committo the culture and cultural elements, norms, values, customs, traditions, specific manners of the community, nationality, race and civilization which are distinct from other societies and have the sense of belonging to them for its growth and evolution. The social identity gives people the impression that they belong to a culture, civilization and their particular nationality. By knowing the culture and ethnicity to which the person belongs, social and cultural identity can be realized and that a person belongs to what society, culture and civilization. This facilitated the rise of national identity for a community (Amin, 2009, p. 13).

2. Stability ofculture:one of the other important factors in forming the identity of a nation is that a nation has a culture with the relative stability and rich historical background. Because every nation has a special attachment to their history and culture and the history and culture of a nation inevitably gives a message to the nation and the messages play their specific role for the identity of their own audiences. Naturally, the attitude toward the culture and history of a nation and the angle at which it was seen in the past is important in this process. It is natural that we should learn the lessons of history and the history of our past can't be viewed with a critical outlook and the historycan't be absolutely acceptedas a pattern for our life. It means that every nation tries to at least look out at the same time by what is adopted from abroad knows its history and the manifestation of its talents and abilities. (Bayani, 2003).

Therefore, sense of belonging to culture, action and adherence to the national and native culture and preservation of the culture elements, including language, customs, traditions, ethnicity, nationality, and race and ..., are causes of the emergence for the stable identity in a society. People, who are sensitive to their own culture, emphasize on using the cultural elegance, commit to customs and social, national and local ethics, put 
extra emphasis on the local language, and the national and ethnic style in a society, never ignore the factors changing the culture. Such people will obtain a stabile culturein the long term. Thus, in light of the culture stability, they witness a constant, dynamic and efficient identity (Nafisi, 2000, p.179).

3. Geography: one of the other components of identity is that a person or a nation has a sense of belonging to the geography and the geographical environment.Today, especially geography is important for boundaries and distinction of identities because it is the constant reference to meet the needs of people's identity.Certainly, identities are better and easier provided when boundaries are drawn more precise, clearer and noninfluenceable.Political geology increases cohesion, and solidarity of groups. This cohesion and solidarity of groups provide context for both national identity (Kaviani Rad, 2010).

4. Religion and religious beliefs: religion and the human relation with it are the other part of identity. The role of religion in the construction of human identity has always been emphasized. Karen Horney said "A person who lacks a composed character and is not able to find positive values stable in culture, religion or ideology will have disrupted ideals. Such a person suffering from identity confusion can't assess the value of his past and will not have the values that help him plan for the future freely (Vitell, 2009, p.604).

\title{
5. Theories on National Identity and Nation
}

There are various theories on the origin and foundations of national identity including primordialism, modern and intermediate.

1. Primordialism: The common feature of this theory is the belief in the history and nature of nations. This theory has three approaches: 1. Nature-oriented approach; 2. Biological approach; 3. culture-oriented approach.

Nature-oriented approach: It is the most extreme approach of this theorywhich considers the national identity as the part of people's nature, just like speaking or seeing. A person has nationality just like having one nose and two ears. A nation to which a person belongs is predetermined and naturally specified. In other words, the person is born in a nation, just as being born in the family. František Palacký, Ewan McNeil, and Nikolai Igor are proponents of this approach.

Biological approach: It starts with the question: why are animals social? Why do they cooperate with each other? Van den Berg is the proponent of this approach, believing that the ethnic identity of the people is an extended term expressing the biological relationship between people.

Culture-oriented approach: This approach is based on the belief that:

\begin{abstract}
Identities or affiliations are eternal and "given", non-derivative and haveprecedence over all experiences and interactions.Primordial sentiments are unspeakable and with force.If a person is the member of the group, he will necessarily feel the special affiliations of and procedures of the group. Ethnic Identity based onprimordialismis fundamentally a matter of feeling and emotion. Schiller, Clifford and Goetz are the believers of this approach (HermidasBavand, 1998).
\end{abstract}

2. Modern theories: the common feature of all the modernist studies is the belief in the novelty of nations and nationalism. According to this approach, both of which (the nation and nationalism) were emerged in the past two centuries,that is to say, at the beginning of the French Revolution. The outputs of modern processes such as capitalism, industrializationare the rise of bureaucracy and government bureaucracy, urbanization and separatism ofreligion from the world. In fact, they are only in the modern world as the social necessity. There was no space for nations and nationalism in the pre-modern era. In short, nationalism hasprecedence over nations and peoples and states don't create nationalism but the reverse is true.Gellner believes that the nation is created by the power to have a single access to the lands which claims sovereignty over them. According to Anthony Giddens, the development of a plurality of nations is basic to the centralization and administrative expansion of state domination internally, since the fixing of borders depends upon the reflexive ordering of a state system. According to Giddens, a nation without a state is an abstract concept. So it must always be considered as a combination of "nation-state".In his definition on the nation-state, he provides a totally stateoriented definition. "A collectivity existing within a clearly demarcated territory, which is subject to a unitary administration, reflexively monitored both by the internal state apparatus and those of other states. It exists only when a state has a unified administrative reach over the territory over which its sovereignty is claimed" (Lyon, 2012).

Hobbes Baum proposed a different attitude toward the modernism. His view on nation and nationalism is part of his broader plan to write the history of modernity. Thus, he interprets nationalism as the natural result of the industrial revolution and political revolt in the last century.According toHobbes Baum, nations and nationalism are products "social 
engineering". The period between 1870 and 1914 can be considered as the period of the innovative of traditions. Invention of tradition was the main strategy that the ruling elite resorted to it to deal with the threat of mass democracy.The currents of nationalism through the National Cathedral, the Royal Family and other religious traditions of solidarity were replaced by social cohesion and became a tool for the existence of groups.(Mojtahedzadeh,2008)

3. The emergence of Smith's intermediate theory and criticism of the idea of Hobbes Baum:

Smith criticizes innovative traditions of Hobbes Baum and claims that they are very close to the "reconstruction" or "rediscovery" of the ethnic aspects. He pointed out that "although the past can be interpreted in different ways but the past does not exist in the past of a certain society with different patterns of events, personalities and circumstances". This past is as an obstacle for elite manipulation and so it is the Invention of tradition. "New" traditions will be accepted by masses until they are proven to have a soul.Smith specifically focused on the origins of the pre-modern of the contemporary nations and ignored the common modernist interpretations which reject the past. His approach is based on the critique of modernism. His main consideration is that modern nations can't be understood without taking into account pre-existing ethnic elements because they are probably major obstacles in the way of "nation-building". As a result, the emergence of the contemporary nations should be studied in the context of their ethnic background. This means that "our understanding of modern nationalism based on historical foundations entails considerable period of time to find out to what extent themes and images of previous periods have already been formed and to what extent the relationship between the early ethnic ties and sentiments can be established". Smith defines the nation as follows: "Human population whose members havethe historical territory, common myths and historical memories, mass of people, public culture, a common economy and common rights and duties". According to Smith, pre-modern identities and heritage form the foundation of many contemporary nations. For such societies, he mentions six main characteristics: (1) the collective proper name;(2) The myth of common ancestry;(3) The common historical memories;(4) A distinctive element of popular culture, or more than one element;(5)A society with the certain territory;(6) feeling of solidarity about an important sector of the population.Most of these characteristics have Historical and cultural content as well as a strong subjective element.As the result of discussion on the nation, Smith believes that when evaluating ties and ethnic communities, we must strive to avoid from the extreme ends of the discussion, that is to say,primordialismandexpressionism.

In discussing nationalism Smith states that this term has been used in five different ways, including:

(1)The whole process of the nation formation and protecting it;(2) Awareness of belonging to a nation;(3) the language and symbols of a nation;(4) an ideology consisting of the cultural theory of the nation;(5)the political socialmovement to achieve the goals of the nation and the national will.

Among intermediate theories, the attitude of people like Hugh Stone and Watson is also important. These theorists believe that there are two kinds of nations, including old nation and new nation. Old nations are the ones who achieved national identity and national consciousness before formulating the doctrine of nationalism, and new nations are the ones that have gone through two processes simultaneously. The formation of national consciousness and creating nationalist movements, both processes were the performance result of the small groups of educated elite, but the process of formation of national identity and national consciousness among old nations was calm and dull.Spontaneous process which didn't involve a minority will was spontaneous and deeper (Nejati Hosseini, 2003).

\section{Theories of National Identity Development}

On the theory of national identity in Iran, various theories have been expressed that after a quick review on some of them, the theory of the philosophical essence is investigated.But first of all, it needs to remember that identity is always versus otherness. The meaning ofalien was found out in early days of the arrival of modernity in Iran. Qajar and Pahlavi era in Iran is the arrival of modernity. In other words, we should say that the project of national identity in Iran was provided after the Safavid era and at the beginning of the Qajar era which was the context of introducing West culture and civilization to the Iranian people. In particular, the official signs of national identity formation were emerged for Iran in the constitutional era which included the establishment of the nation-state. Iranian national identity was made through social engineering in the historical era of constitution and the first Pahlavi. The emergence of nationalism is the new signs of Iranian identity formation. Intellectuals played the most important role forthe Iranian identity formation in this era (Janet, 1996).

In fact, the first messengers of the Westcivilization were the students studying abroad and bureaucratic officials who had been sent to Russia and Europe. MirzaAbolhassan Khanilchi (the bureaucratic official as the ambassador) and MirzaSalehShirazi as the student were sent abroad.They were intimidated by the West.Abolhasan Khan wrote his itinerary called "a wonder of the west" for ambassadors (Foran, 1999, p. 422).

From this period onwards, some kinds of identity were formed with various elements.

1) Discourse of religion-oriented Iranianness: Talbof was one of the intellectuals in the Qajar era and the 
missionary of the identity of religion-oriented Iranianness. He investigated reconstruction of nationality in the modern sense and the religious element in the era of Enlightenment's modernization. There are Words such as nationality, national development, national bodies, national mobilization and love of country in his literature. According to him, people must be familiar with their rights to achieve national unity and the development of education. He is correlated with the pattern of European modernization.In his view, where there is no freedom, there is also no love of country. He emphasized on the reconstruction of the nationality based on two elements of Iran and Islam as two components of selfesteem and finds them consistent with civil and industrial, scientific and cultural achievements. The dominant discourse of new Iranianness in this time is religion-oriented Iranianness (Akbari, 2005).

2) Discourse of secular and ancient-oriented Iranianness:MirzaFataliAkhundzadeh and MirzaAqa Khan Kermani were intellectuals in the Nasserist era who considered language, writing, history, religion and progress as the basic elements of the national identity. Akhondzadehinvestigated definition of own or Iranian throughthe otherness of the project. The recovery of identity should start from "other" and it is removed from "other". The removal of "other" includes writing, language, religion, culture and legacy of the government system. He found Islam and religion uncultured and considered the religion asthe misery of Iranian people. He considered the Zoroastrian religion as the religion of Iranians and sometimes consideredthe new Western civilization as the Iranian religion. Interestingly, Akhondzadeh believed that "other" is not alien andthe west is part of Iranian identity for the renewal of the new Iranian identity. Acceptance of Western culture is for the recovery and self-assessment, but the acceptance of Islam is a kind of betrayal (Akbari, 2005, p. 67).

Then, aria-orientation or archaism projects continued and promoted after the constitutional era and during the first Pahlavi era. The modernist movement ended by the defeat of the constitution. The discourse of nationalism or Aryan is the same discourse of identity for the intellectuals in the Nasserist era. Reza Shah's plan for modernizing Iran is the same plan of the intellectuals. Reza Shah sought the complete elimination of religion from the society, removal of religious scholars from the social and political scenes and changing the traditional educational system (religious), prohibiting the practice of religious rituals, unveiling the Hijab, the Western legal system without the influence of religious scholars, the revival of Aryan identity, and Zoroastrian religion. This discourse separated the Iranians from their indigenous identity and related the achievements of the Islamic period to the Iranian civilization and race and along with ancient identity. Furthermore, this discourse introduced Shiite as the Iranian-made religion. It also emphasized on the Nationalist ideology and considered race, blood, history, single culture, religion, geography and single government as the constructive factors of the nationality. This discourse also emphasized on the Aryan race as a unifying and constructive element of Iranian nationality (Kachoeian, 2005).

3)Nation state project and Iranian national identity: Along with the above discourses, the project of national identity considers the people of the society as a nation who have a sense of belonging and connection with each other.A sense of belonging to the land called country is one of the other aspects of the project of national identity.Nation means the sense of belonging to each other as well as attachment to the land and Geopolitics. In the political literature of this era, homeland is considered as the mother whose children are all citizens without any distinction. Addressing the issue of homeland is considered important as part of the project of the constitution and the establishment of appropriate national government. The emergence ofconstitution and the new European political literature were widely formed by social forces and associations. Constitution and the arrival of the new government developedpolitical discourse based on the modern nation-state. Using new tools such as the press, parliament and speech, Elite considered the European version of the discourse as the only way to treat the pain of the nation. Eliteadded the establishment of nation-state and the national government through the national solidarity based on national interests and achieving happiness as the dimension of the new discourse (Kachoeian, 2005, p. 96).

4) Philosophical theory of nature and Iranian identity: The main theory about the formation of Iranian national identity is philosophical theory of the essence. The essencetheory is an approach for the understanding of national identity and the issues surrounding it. According to this theory, noting the fundamental and original layers is essential for the understanding of national identity and the subjective and objective phenomena of national identity should be investigated from this perspective (Najafi, 2006). The question of national identity is basically philosophical. Only philosophy discusses the existence of something and considers the intrinsic elements. It is the knowledge which considers objects without any distinction and privilege. So from the perspective of the philosophy, the question of national identityis a research on the essence of the nation. Therefore, according to the philosophy, considering the elements, including only race, language and history, for the understanding of national identity is not appropriatebecause such elements are decomposedwhen investigated by the philosophy. From the philosophical perspective, such elements arethe manifestation of the nationalityrather than its essence. Thus, the way to achieve the true response of nationality is in the light of philosophical questions and other understandings will be based on it (MahdaviZadegan, 2002). 
The identity of a nation, in other words, requirement for the creation of a nation, includes reaching the joint pain, common ideal, sense of community, the ability of a nation to feel, demand, understanding and shared vision of own and reaching the ideal. This results in the collective development, culture and tradition making for a nation. Therefore, responding to the nature the identity of an object should be toward the nature of Iranian society (national identity). In this case, responses will be definitive.Peace of mind and certainty of respondents are achievable by relying on the fact of the matter (Najafi, 2005).

Therefore, in responding to the nature of the identity, the response should be sought in cases where it is associated with nature because identity is versus otherness which is appropriate for theworld of diversity and the essence meansa fixed matter. Each Iranian person has something in himselfwhich represents his nationalityand distinguishes him from non-Iranian people. Behavior, actions, and housing and business are not related toone's being Iranian. Culture is the origin of the effect. Behavior and ... are something unrelated to Iranianness. The Iranians live in many foreign countries for many years and are quite distinct from others. For example, Iranians living in America have their Iranian customs and speak Persian and preserve their identity. Iran's history must not include rise and fall of thedynasties of Sassanid, Seljuk, Achaemenid, etc.Iranian identity is common among all the dynasties.We are an Iranian society who live in a particular geographic location, speak the Persian language, and have special customs, beliefs, values, ethics and religion (DavariArdekani, 1995).This is the essence of the nation which has always been with it in the history and distinguishes Iranian from non-Iranian.

\section{Iranian Identity Elements in the Essence Theory}

As mentioned, the identity of a nation and the people means the dignity for the privileges and the features of the land.Most obvious notion of identity is included in the culture. The social, political and historical role of a country's culture should be analyzed.The culture of a nation has religion, language and race. . Precious spiritual treasures in the spirit of Iran before the Islam have been effective in the evolution of justice and result in the important historical legacy. Such treasures resulted from the heart of the history are vital for Iran. For example, during Ghaznawids the official religion in Iran was Sunni and the religion couldn't be the common feature for the Iranian national identity. But the common feature and criterion was the Persian language. In the fall of Baghdad and Safavid caliphate, Iran identity feature was theosophy and mysticism which gave identity to Islamic Iran with the Persian language.but were always dominated by the Ottoman Empire and lost their identity. Later, with the establishment of Western culture, the Arabs faced with another identity crisis in the form of extreme nationalism and were surrendered by the secular modernism (Najafi, 2006).Language was the factor of linking Iranians after accepting Islam. The Arabic language was expanded among Iranians after Islam because (1) the Arabic language was the language of the Quran and the Islamic international language for Iranians; (2) Development of Arabic grammar was done by Iranians even for native language Arabs; (3) Iranians accepted only the Arabic language because it was in harmony with religion, they accepted no other language even the dominant Mongolian language; (4) Iran was the largest non- Arabiclslamic community and Iranians accepted this language when there was no Arabic reign in Iran, even caliphate of Baghdad was established by the Diyalameh reign; (5) Arabic was the language of Islamic scholars. Both Arabic and Persian languages were spoken in Iran.Written works of Avicenna and Abu Rayhan were in Arabic and Ferdowsi in Persian. (Ajdani, 2006).

Every nation has its own nature expressing the truth.This fact is the national spirit of a nation. Islam among Iranians is synchronized with this nature. This nature is coordinated and consistent with the element of religious ideology and is a kind of truth-seeking and religiosity for Iranians. There is a kind of fascination and harmony between the elements of nature and the identity is strengtheneddeveloped in the national Iranian nature over time. Every time throughout history, the elements, including the Iranian, Shiite, Persian, defended the nature, identity and their culture in the geographic area of Iran, the essence and the spirit of Iranians along with independence and Islam were progressive and Iranian people always tried to remove all the obstacles facing them. The crisis caused by the conflict among Iranians' expectations from Islam, Islamic justice seeking, corruption within the governments, and oppression of the Muslims was the underlying emergence of movements among Iranianswhich led to the formation of the National Iranian essence of the spirit. The essence of Iranian national spirit along with spirituality seeking, truth seeking and justice seeking has maintained thereal identity of Iran (Tavasoli, pp.31-33).

\section{The Historical Process of the National Identity Formation in Iran}

According to the philosophical theory of essence, the process of Iranian national identity formation cab be stated as follows: 
The Essence theory does not considerthe elements of the Iranian national identity limited to the Qajar and Pahlavi era. Iranians during the history of their ups and downs, one after another,recovered their true identity and identity elements. The Iranian ancient civilizing tribes lived on the Iranian plateau which stretches from river Oxus to Zagros ranges. It entered a new phase three thousand years ago with the coming of the Aryans, and its outstanding example is the Persian Empire. Iranian territory was covered by Zoroastrianism and according to Herodotus, Achaemenid knew Persia as the heart of the world. From then until the fall of the Sassanid and the emergence of Islamic in Iran, Greeks and then Romans were the serious competitors of Iranians. By this time, Iran played the role of the superpower of the East. It had serious competition with the West and the supporter oflranian culture. The Achaemenid, Parthian and Sassanid civilization and culture were always prevailed (Salasi, 2008).

From then on and after the fall of the dynasty, the great Iranian empiresand the destruction of the empire of the East, Iran faced with various crises. It can be said that Iranians faced with four identity crises: (1) Hellenistic crisis; (2) Turkish Crisis (Mongol); (3) Crisis Arabic (the arrival of Islam by the Arabs); (4). Western crisis (modernity);among these crises, only Arabic and Western crisis had the tool of identity-making. . Iranians accepted Islam and allowed these religions to be in the core of their essence. But they have not yet accepted western culture and identity despite having the identity making tool in the west crisis after 200 years. With the advent of Islam, there was a peace for the soul of justice and Iranian spirituality. Iranians want to consider the identity and epistemological and ontological components of the new Islam as part of their identity. There was a problem from which the Iranians suffered during the Umayyad Caliphate accompanied by the Arabic nervousness and priding. In addition, the Abbasids prevented the Islamic justice and national political sovereignty for Iranians. Finally, the Safavid dynasty was formed in the tenth century (Najafi, 2006) and Iranians achieved the independent political sovereignty.

Therefore, the existence of common land for the Iranians, with elements of Shia Islam, along with the formation of an independent Shiite state in the tenth century caused the Iranians to achieve their real identity. In other words, in the past history of Iran, there were three elements in Iran: Islam, Persian language, Geographic region. Shia Safavid Empire was the most prominent form of state established in Iran as an independent national state. In fact, it is the core of Iranian national identity. In addition to the three mentioned elements, there are three essential elements,including Iranian, Islamic and Shi'ite, which have always been compatible withlranian national identity:

1. Ancient Iran's identity: elements which the Iranians had with themselves fromtheir historical past to the rise of Islam. National customs, including Nowruz,are at this level and influence on the Iranian culture.

2. Iranian Islamic identity, which has been formedduring nine centuries. The emergence of thinkers such as Ferdowsi, Saadi, Hafiz, Molavi, Avicenna, Suhrawardi, and Biruni, etc. is at this level. They are Muslim scholars who were involved in the construction of the Iranian identity.

3. Iranian Shiite identity; this identity was formally formed after the Safavi dynasty. The historical truth of Iran includes the three interconnected networks in the form of Shiite civil system: the political system of the Safavid to the constitution for four centuries; from the constitution to the Islamic Revolution; from the victory of the revolution in 1357 until now.Thus, the spirit of the Islamic Republic of Iran includesShiite thought and Iranian traditions. Thus, the Shilite, Islamic, and Iranian identity is the new Iranian national identity(Najafi, 2006, p.28).

\section{Inseparability of Iranian Identity and Islamic Identity}

There a few nations like Iran continuously involved in identity crisis. The main reason is the geographic location of Iran in the Middle Eastas a gateway for East and West. Because of this location, Iran has always been invaded bythe different ethnic groups during the history. Iran has tried in various ways (such as the influence of KhajeNasirodinTusi, the Mongols, Al-Kunduri, andKhajeNizam al-Mulk on the Seljuk Turks) to prevail Iranian culture over the culture of the invaders. However, the culture and civilization of Islam and the West have had the indelible influence on thelranian culture and civilization and Iranians can't abstain from the influence of the culture and civilization of Islam and the West (Bartold, 1970).

\section{Summary and Conclusion}

According to what mentioned, the theory of "Essence" is an approach to understand the national identity because it focuses on the essence of identity. Identity will never be identified except by referring it to the most fundamental inner layers. Essence of national identity, which is the national spirit, is a perspective on issues surrounding identity. According to the theory of "Essence", identity issues should be investigated through the truth of the same identity, unless the issues 
derived from another identity. However, for the understanding of national identity as well as recognition of the inherent issues from other issues, all things should be referred to the essence. Even if the essence theory is not considered as a method, it can be an approach to reach a way for determining a method. For this reason, this theory is systematic. This theoryleads the researcher to a particular way of understanding the national spirit.

Todays, the secular world with all its existing capacity fights with national and religious identities, makes new identities for nations through national and transnational media and promotes the secular identity. In the meantime, the west wants to promotethe single universal culture, that is to say, the globalization of Western and secular culture, and remove the national and religious identities. Thus, we must recognize our national and religious identity which forms our real identity and is based on our nature and existence, and national spirit. In addition, we must resist against the secular word, which wants to remove our identity, and know fake and untrue identities not consistentwith our national spirit and identity.

We can conclude that the factors that determine a nation's identity include specific cultural system, geography, law and rules between people and the government, language, and historical legacy. By studying historical periods in Iran, we can pursue the development of the Iranian identities.For this reason, the history of Iran is categorized with regard to the four crises, including Hellenistic, Arabs, and West. First period: The period of development of the nation and national identities coinciding with formationof the first identity factors of Iranian crisis (the emergence of Zoroastrianism, the Medes, the Achaemenid, ancient Iranian thought,and idealized Iranian monarchy). Second period: the period of the nation without people (the Arabs invasion). Third period: struggling to form a state from Saffarids onwards. Fourth period: Safavid period and the formation of an independent national state.

In short, the essence of national identitycan be summarized as follows:

1. The sense of national unity is resulted from the sense of belonging to home and family, kinship, and tribe.

2. The sense of national unity is the function of human growth and progress in the society, and the product ofdirect or indirect promotion and education.

3. The sense of national unity and solidarity affected by micro or macro culture can be weakened or strengthened.

4. During development, the government induction,the sense of national solidarity and its reflection in mass media can exacerbate or mitigate the emotional burden toward "own" and "others".

5. Mobility and cultural, societal andspatial development extend comorbidity within the country and outside the country without breakingthe emotional ties with minor comorbidity. Thus, induction and motivation resulted from a nation must not remove comorbidity of the small community, ethnic, tribal, and family.

6. Historical, political and societal events, such as foreign aggression, war, defeat and, martial, sports and elections victory play a vital role in stimulating, strengthening or weakening solidarity with "own", evoking the sense of revenge and anger against the "others".

The following suggestions are presented forthe strengthening of Iranian national identity:

1. Education in the community should have a special place because reconstruction and stability ofthe country's identityare through this institution.

2. To care about the national identities, we must not fearthe effects of the Islam and West culture and boostour cultural capital by addingthe positive aspects of such culturesand make them indigenous.

3. We must consider Islam as the superior religion, use it inthe various aspects of life, and consider the west as a powerful competitor and not underestimate it.

4. We must try to strengthen the positive aspects of Islamic-Iranian identities, remove the identities defects, and never try to separate them from each other.

5. It must be internalized among people that the cultural diversity in Iran does not conflict with national identities and causes them to recognize the different ethnic groups and cultures and consequently leads to their growth.

6. We must consider the cultural diversity as a value because it strengthens the identity. Consequently, the acceptance of cultural diversity leads to the sense of loyalty and belonging to the common elements and symbols in the national community, and ultimately the national identity.

7. Government officials need to address the factors that undermine the identity. They must also address: (1) the revival of building trust and people care about their plans and try to perform them; (2) Implementation of social justice in the society and thereby reducing the distances between people as well as creating a national consensus between them; (3) gathering people to have more interactions and they are more familiar with each other through the communication and ultimately love their country. 


\section{References}

Adany. L, (2006). Escape from the conflict of reality by the history. Iran newspaper, January 5.

Ahmadi.H, (2003). National identity in the context of history.Publication of scientific studies, Issue 1.

Amin. H, (2009). Historical consciousness and national identity.specialized educational, research, and analytical journal of Padang, volume 6 , issue 59 , pp. 11-15.

Iman. M.T, Rohani.A, (2013). The relationship between national identity and social capital (Case Study: students of Shiraz University). Social Sciences Journal of Islamic Azad University, Shushtar branch, volume 7, issue 22, pp. 37-62.

Akbari. M.A, (2005).Genealogy of the new Iranian identity, the Qajar and first Pahlavi era. Tehran.scientific and cultural publications.

Bayani. Sh (2003). Historians and national identity (1).National studies jouranl, volume 4, Issue 1.

Berthold, Ashpoler (1970). History of Iran In the early centuries of Islam.Flatory.J, the firm of Translation and Publication.

Tavasoli.M, (without date).National and religious identity; support of the Iranian nation. Iran's perspective, issue18.

Salasi. M, (2008).Iran and the international world, analysis of the world-oriented approach on the behavior, culture and history of Iran. Fifth Edition, Tehran: Markaz Publication.

Khalili, R. (2005). The development of interaction between religion and identity in the thoughts of Imam Khomeini.National studies journal, volume 8, Issue 2.

Dehshiri, M. (2001). Globalization and national identity.National Studies journal, volume 2, Issue 4, pp. 5-27.

Dashti. M, (1995) Iranian people's historical identity, recognition some aspects in the ancient era.Marefat journal, issue 65.

DavariArdekani , R. (2000). West and identity crisis in Iran, about the West. Tehran: Homes publication, Chapter 4.

Rajaee. F, (2002).Todays' problem of Iranian identity. Tehran: Ney publication.

Zahed. S, (2005). Iranian national identity.Yas strategy, volume 1, issue 4.

Shekhavandi. D, (2001).Development and implementation of identity. Tehran: recognition center of Islam and Iran.

Foran. J, (1998).Fragile resistance, history of social transformations, translated by Ahmad Tadayon, Tehran: Rasa.

Fakobi. N, (2002).Identity formation and local, national, global patterns. Tehran: journal of Sociological Association.

Kaviani Rad, M. (2010). Region-orianted in Iran from the geo-political landscape. Tehran: Research Center for Strategic Studies.

Kachoian. H, (2005).Evolution of Iran's identity discourse (evolution of Iran's identity discourse ). Tehran: Ney publication.

MoeiniAlamdari. J, (2004).Identity, history and tradition in Iran. Tehran: Institute for Humanities Research and Development.

Mojtahedzadeh. P, (2008).Democracy and Iranian identity. Tehran: Kavir publication.

MahdaviZadegan. D, (2002).Approach to the theory of "essence" for the understanding of national identity in components of national identity in Iran, the political research group of Islam, Tehran: Institute for Humanities and Cultural Studies.

Motahari, M. (1986). Mutual services of Iran and Islam. Tehran: Sadra publication.

Nejati Hosseini. S.M, (2003).Analysis of historical identity, historiography and historical sociology, theoretical and methodological considerations.Journal of the National studies. Volume 4, Issue 1.

Nafisi. R, (2000).Political culture and national identity.Journal of National Studies, volume 2, Issue 5, pp. 177-191.

Najafi.M, (2006).Development and formation of national identity. Tehran: Cultural Institute of knowledge and contemporary thought.

HermidasBavand, D. (1998). The challenges of cross-border and Iranian identity throughout history.Journal of political and economiclnformation, volume 12, issue 129-130.

Erikson, E. H. (1959). Identity and the lifecycle. International Universities press, New York.

Janet Afary, The Iranian Constitutional Revolution, 1911-1906: Grassroots Democrcy, Social Democracy, and the Origins of Feminism, (New York, Columbia University Press, 1996).

Leonard,G.R. (2010). Moral identity in adolescence:A literature review, University of Asuza, California.

Lyon, D. (2012). Postmodernity. New York: Columbia University Press.

Vitell, Scott John., et all. (2009). Religiosity and Moral Identity: The Mediating Role of Self-Control. Journal of Business Ethics, 88, 601613. 